http://dx.doi.org/10.1590/1678-4162-9599

Arq. Bras. Med. Vet. Zootec., v.69, n.6, p.1496-1502, 2017

\title{
Quantification of Treg cells in peripheral blood and lymph nodes of dogs with multicentric lymphoma
}

[Quantificação de células Treg no sangue periférico e linfonodos de cães com linfoma multicêntrico]

\author{
L.A. Anai ${ }^{1}$, T.D. Munhoz ${ }^{2}$, L.M.S. Semolin ${ }^{1}$, N.P. Reis Filho ${ }^{1}$, E.M. Terra ${ }^{1}$, P.C. Jark ${ }^{1}$, \\ D.M. Fonseca ${ }^{3}$, A.F.S. Nogueira ${ }^{4}$, M. Tinucci-Costa ${ }^{1}$, A.E. Santana ${ }^{1}$ \\ ${ }^{1}$ Universidade Júlio Mesquita Filho - UNESP - Jaboticabal, SP \\ ${ }^{2}$ Centro Universitário Barão de Mauá - Ribeirão Preto, SP \\ ${ }^{3}$ Colégio de Medicina - Universidade Estadual Paulista - São Paulo, SP \\ ${ }^{4}$ Universidade Federal do Piauí - Bom Jesus, PI
}

\begin{abstract}
Lymphoma is a malignant tumor characterized by cell proliferation of lymphoid origin and corresponds to $90 \%$ of all hematopoietic neoplasms of dogs. Regulatory $\mathrm{T}$ cells (Tregs) have been the target of many investigations in oncology due to their potential of down-regulating immune responses, as well as ensuring the maintenance of active mechanisms of tumor suppression. The aims of the present study were to compare the percentage of Tregs in peripheral blood between dogs with multicentric lymphoma and healthy animals, together with the percentage of Tregs in peripheral blood and lymph nodes of dogs with multicentric lymphoma. Twenty-six animals were enrolled in the study: 10 healthy dogs comprised the control group (CG) and 16 dogs with multicentric lymphoma comprised the Lymphoma Group (LG). We observed that dogs in the LG showed a significantly higher Tregs expression in peripheral blood compared to the CG. No significant difference was observed between Tregs expression in lymph nodes and peripheral blood of the LG, however. With these results, it is possible to conclude that multicentric lymphoma is a neoplasm with high Tregs expression, which poses this as a condition of interest when investigating treatments that can suppress Regulatory $\mathrm{T}$ cells.
\end{abstract}

Keywords: regulatory T cells, canine, lymphoma, Foxp3

\section{RESUMO}

O linfoma é uma neoplasia maligna caracterizada pela proliferação neoplásica de células originadas de tecido linfoide e corresponde a cerca de $90 \%$ das neoplasias hematopoiéticas em cães. Células $T$ reguladoras (Tregs) têm sido alvo de diversas investigações na área da oncologia devido ao potencial de regulação negativa da resposta do sistema imune e à manutenção ativa do mecanismo de imunossupressão tumoral. O objetivo do presente estudo foi a comparação da porcentagem de Tregs no sangue periférico entre cães com linfoma multicêntrico e animais saudáveis e a porcentagem de Tregs no sangue periférico e nos linfonodos de cães com linfoma multicêntrico. Foram utilizados 26 animais: 10 cães saudáveis, como grupo controle (CG), e 16 cães com linfoma multicêntrico, como grupo linfoma (LG). Observou-se maior expressão de Tregs no sangue periférico de cães do LG em comparação ao CG. Entretanto, não foi observada diferença significativa entre as expressões de Treg nos linfonodos e no sangue periférico do LG. Com esses resultados, foi possível concluir que o linfoma multicêntrico apresenta alta expressão de Tregs, tornando-se condição interessante para o estudo de tratamentos capazes de suprimir as células $T$ reguladoras.

Palavras-chave: células T reguladoras, canino, linfoma, Foxp3

Recebido em 24 de novembro de 2016

Aceito em 11 de fevereiro de 2017

E-mail: letanai@hotmail.com 


\section{INTRODUCTION}

Lymphoma is a malignant tumor characterized by cell proliferation of lymphoid origin, such as lymphocytes, histiocytes and its precursors and derivatives. The disease primarily affects lymph nodes or other solid visceral organs such as the liver or spleen (Contran et al., 1994; Vail and Ogilvie, 1998).

This tumor is one of the most common neoplasms of dogs, comprising 8.5 to $9 \%$ of all canine neoplasms (Dobson et al., 2001), and corresponds to approximately $90 \%$ of all hematopoietic tumors of dogs (Rosenthal and Macewen, 1990; Morrison, 1998; Fan and Lorimier, 2005). Traditionally, canine lymphoma is classified as multicentric, alimentary, mediastinal, cutaneous or extranodal, according to its anatomical distribution (Vail and Ogilvie, 1998), being the multicentric localization related to $91.2 \%$ of lymphoma cases in dogs (Sequeira et al., 1999).

The physiological and pathological functions of Regulatory $\mathrm{T}$ cells have been the target of intense research, since these cells can act on normal immune responses and pathogenic conditions such as infectious, allergic, neoplastic and autoimmune diseases (Cools et al., 2007). The main function of Tregs is to down-regulate immune responses, ensuring the maintenance of active mechanisms of suppression (Cruvinel et al., 2008).

Natural Regulatory T cells express CD4 and CD25 (high affinity to interleukin-2 receptors) and are also transcribed by the Foxp 3 factor (Banham et al., 2009). In dogs, Tregs were identified using specific antibodies against canine CD4 and murine Foxp3 (Biller et al., 2007; Keppel et al., 2008; Banham et al., 2009; Horiuchi et al., 2009; O'neill et al., 2009).

In human medicine, an increase on Tregs population in peripheral blood and tumoral sites occurs in cancer patients (Ichihara et al., 2003; Ling et al., 2007). In veterinary medicine, some authors observed a significant increase in Tregs of dogs with cancer compared to healthy dogs (O'Neill et al., 2009). Other authors found that Tregs were significantly higher in dogs with metastatic tumors than in dogs with nonmetastatic tumors (Horiuchi et al., 2009).
Moreover, it has been shown that the more aggressive the tumor, the greater the number of Tregs. Additionally, these cells were preferentially present in the sentinel lymph nodes of tumors (Biller et al., 2007).

In women with advanced breast cancer, a high Foxp3 expression was observed in sentinel lymph nodes, according to other previous studies regarding various cancer types (Mandsfield et al., 2009). In dogs with oral melanoma, a significant increase was identified in Tregs at tumoral sites compared to the peripheral blood of the same dogs (Tominaga et al., 2010).

Thus, the aims of this study were to compare the percentage of Tregs in peripheral blood between dogs with multicentric lymphoma and healthy dogs, as well as to compare the percentage of Tregs between peripheral blood and lymph nodes of dogs with multicentric lymphoma.

\section{MATERIAL AND METHODS}

The study has been approved by the local Ethics Committee for Animal Use (Faculty of Agricultural and Veterinary Sciences, UNESP, Jaboticabal - protocol no. 027665/10).

A total of 26 dogs were included in this study. All animals were attended to at the Veterinary Hospital of the institution. Patients were divided into two groups, as follows: 16 dogs with histological diagnosis of multicentric lymphoma (LG, animals previously treated for lymphoma were excluded); 10 healthy dogs with no history of tumors and other subjacent diseases for the control group (CG). Dogs from the LG were also submitted to thoracic radiographs and abdominal ultrasound for clinical staging.

Following the diagnosis of lymphoma, a $15 \mathrm{~mL}$ blood sample was obtained from the jugular vein of the LG subjects to heparinized tubes. Lymph node samples were collected through aspiration and stored in saline. Both peripheral blood and lymph node samples were processed immediately after collection.

For dogs in the CG, $15 \mathrm{~mL}$ of blood was obtained from the jugular vein following clinical and laboratorial examinations in order to exclude subclinical diseases. Blood samples were stored 
into heparinized tubes. Lymph node samplings were not performed on CG dogs.

Based on the methods described by Biller et al. (2007), mononuclear cells were isolated from $15 \mathrm{~mL}$ blood samples obtained by venipuncture and stored in heparinized tubes. Blood was immediately diluted (volume:volume) in PBS sterile solution and separated to Ficoll-Hypaque gradients with a density of $1.077 \mathrm{~g} / \mathrm{L}$ (FicollPaque PLUS, Amersham Biosciences, Sweden). Following 30 minutes of centrifugation at $720 \mathrm{xg}$, mononuclear cells were collected, resuspended in PBS solution, and centrifuged at $720 \mathrm{xg}$ for 10 minutes. The supernatant was discharged and leucocytes were resuspended in $2 \mathrm{~mL}$ of erythrocytes lysing buffer $\mathrm{ACK} \quad\left(\mathrm{NH}_{4} \mathrm{Cl}\right.$ $0,15 \mathrm{mM}, \mathrm{KHCO}_{3}$ - $10 \mathrm{mM}$, EDTA - 0,1mM; $\mathrm{pH}=7,3)$ for five minutes and recentrifuged. Washed cells were resuspended in $1 \mathrm{~mL}$ PBS solution and then diluted (1:20) in $0.5 \%$ trypan blue for Neubauer chamber counting.

Cells were divided into six tubes for each subject, as follows:
Tube 1: only cells with no labeling

Tube 2: cells labeled for control isotypes

Tube 3: cells labeled with CD4:FITC, PanT APC and CD8 antibodies

Tube 4: only cells with no labeling

Tube 5: cells labeled with control isotypes

Tube 6: cells labeled with CD4:FITC, PanT APC and Foxp3 PE antibodies

Control isotypes and antibodies are presented at Table 1. In tubes 1,2 and $3,1 \times 10^{6}$ cells we used. In tubes 4, 5 and $6,2 \times 10^{6}$ cells were used. The latter cells were processed for membrane permeabilization, using permeabilization/fixation and permeabilization solutions (eBioscience ${ }^{\circledR}$, ref 00-5521-00), according to manufacturer's instructions. Before membrane and cytoplasmic labeling, $5 \mu \mathrm{L}$ of an autologous serum (previously incubated in a $56^{\circ} \mathrm{C}$ water bath for 30 minutes) were added to each tube in order to unblock unspecified reactions and incubated for 30 minutes for membrane labeling and 15 minutes for cytoplasmic labeling. At the end of the process, $100 \mu \mathrm{L}$ of $1 \%$ PBS-formol solution were added for cell preservation.

Table 1. Main control isotypes and antibodies used in flow cytometry with its respective fluorochromes, manufacturer, clones and volumes used

\begin{tabular}{|cccc|}
\hline Control isotypes & Manufacturer & & Volume \\
\hline Mouse IgG1-Negative Control FITC & AbD Serotec & & $1 \mu \mathrm{L}$ \\
Rat IgG2a Iso Control PE & EBioscience & & $1 \mu \mathrm{L}$ \\
APC Mouse IgG1k Isotype Control & BD Pharmingen ${ }^{\text {TM }}$ & & $1 \mu \mathrm{L}$ \\
\hline Antibodies & Manufacturer & Clone & Volume \\
\hline Rat anti dog CD4:FITC & AbD Serotec & YKIX302.9 & $1 \mu \mathrm{L}$ \\
Rat anti dog CD8:RPE & AbD Serotec & YCATE55.9 & $1 \mu \mathrm{L}$ \\
APC mouse anti dog PanT cell marker & BD Pharmingen ${ }^{\text {TM }}$ & FJK-16s & $1 \mu \mathrm{L}$ \\
Anti mouse/rat Foxp3 PE & EBioscience & LSM 8.358 & $2 \mu \mathrm{L}$ \\
\hline
\end{tabular}

For lymph node sample processing, the same technique described above was applied, being the only difference the filtration with Cell Strainer

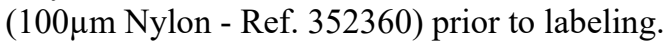

Flow cytometry was performed at a maximum interval of 24 hours following blood collection. Cell preparations were obtained on BD FACSCanto II equipment. Fifty thousand events per tube were registered and analyzed by the FlowJo software. A flowchart representing the gates is represented in Figure 1.

A non-parametric analysis of variance was performed (Kruskal-Wallis test). Pair comparisons were performed using Dunn's posthoc test. Results were considered significant when $\mathrm{P}<0.05$. Analyses were performed by GraphPad Prism 5 (GraphPad Prim5 software package, GraphPad Software, San Diego, CA, USA).

\section{RESULTS}

A total of 42 samples were obtained for Tregs quantification: 32 samples from the LG (16 from peripheral blood and 16 from lymph node aspirates) and 10 peripheral blood samples from healthy dogs, as described at Table 2 . 

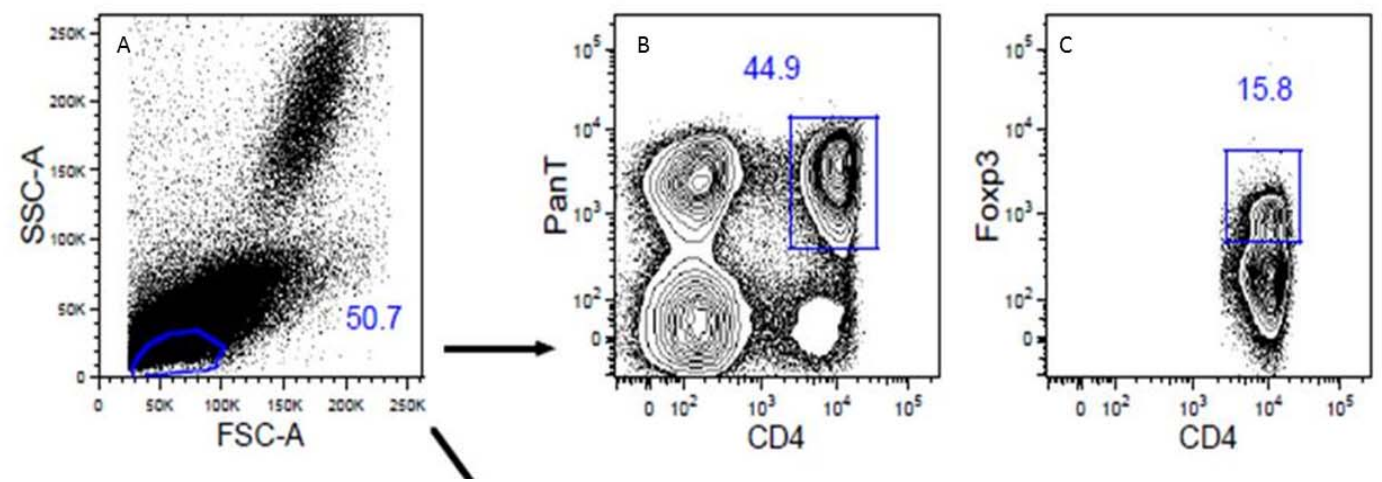

Figure 1. Flowchart representing lymphocyte gates for analysis of regulatory $\mathrm{T}$ cells from peripheral blood in canine multicentric lymphoma. A) Lymphocyte gate; B) T CD4 $4^{+}$gate (PanT); C) Foxp3 $3^{+} \mathrm{CD} 4^{+}$ lymphocytes (Tregs) gate.

Table 2. Quantification of regulatory $\mathrm{T}$ cells in lymph nodes and peripheral blood of dogs with multicentric lymphoma (Lymphoma Group - LG) and in peripheral blood of healthy dogs (Control Group

\begin{tabular}{|ccccc|}
\hline \multirow{2}{*}{ LG dogs } & Lymph node & Peripheral blood & \multirow{2}{*}{ CG dogs } & Peripheral blood \\
\cline { 2 - 3 } & Tregs(\%) & Tregs $(\%)$ & 1 & Tregs $(\%)$ \\
\hline 1 & 27.32 & 17.13 & 2 & 5.16 \\
2 & 38.66 & 19.39 & 3 & 5.2 \\
3 & 22.3 & 18.71 & 4 & 3.62 \\
4 & 32.16 & 44.72 & 5.28 \\
5 & 47.7 & 42.5 & 5 & 6.03 \\
6 & 8.9 & 38.5 & 6 & 6.95 \\
7 & 14.1 & 10.5 & 7 & 5.52 \\
8 & 12.3 & 6.12 & 8 & 6 \\
9 & 28.6 & 17 & 9 & 3 \\
10 & 10.1 & 3.6 & 10 & $*$ \\
11 & 19.6 & 17.6 & $*$ & $*$ \\
12 & 10.9 & 8.15 & $*$ & $*$ \\
13 & 31.5 & 20.5 & $*$ & $*$ \\
14 & 45.1 & 32.5 & $*$ & $*$ \\
15 & 26.3 & 5.35 & $*$ & $*$ \\
16 & 10.1 & 20.4 & $*$ & $*$ \\
\hline
\end{tabular}

The peripheral blood of LG dogs showed a significantly higher percentage of Tregs (20.17 \pm 3.25$)$ compared to that of healthy dogs (4.70 \pm 0.50$)$. However, when comparing the percentage of Tregs between peripheral blood $(20.17 \pm 3.25)$ and lymph nodes $(24.10 \pm 3.17)$ of dogs with lymphoma, no significant difference was observed (Figure 2).

\section{DISCUSSION}

Regulatory T cells play a fundamental role in the maintenance of lymphoid homeostasis in many circumstances that involve the immune system, such as: aiding the maintenance of microbial flora, controlling autoimmune reactions and also helping tumors escape from immune surveillance. However, different Tregs lineages participate in these phenomenon and can be divided into two subgroups: Natural Tregs that develop from the thymus due to a regulatory process; and Induced or Adaptive Tregs that emerge from peripheral sites by conventional $\mathrm{T}$ cell activation in a microenvironment rich in regulatory cytokines, or following interaction between Natural Tregs and conventional $T$ cells in a process known as infectious tolerance (Feuerer et al., 2009; Sakaguchi, 2008; Garden et al., 2011). 


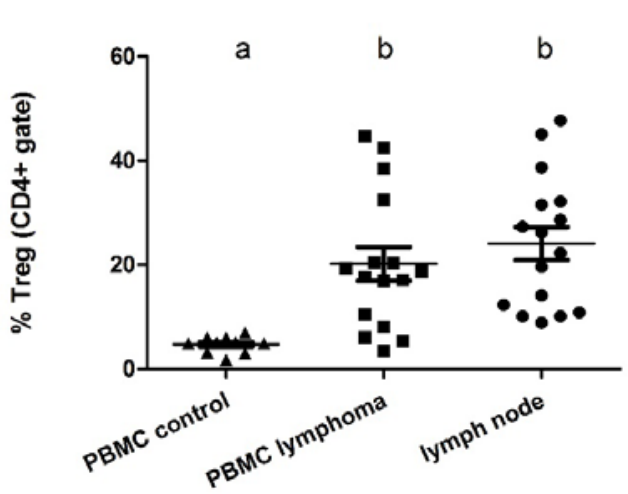

Figure 2. Comparisons of the percentage of regulatory $\mathrm{T}$ cells $(\mathrm{CD} 4+$ gate) from peripheral blood of healthy dogs (PBMC control), peripheral blood of dogs with multicentric lymphoma (PBMC lymphoma) and lymph nodes of dogs with multicentric lymphoma (lymph node).

A previous study demonstrated that the percentage of Tregs in the blood of healthy humans and rats varies from 5 to $10 \%$ of all $\mathrm{T}$ $\mathrm{CD}^{+}$cells (Itoh et al., 1999), which corroborates the findings of the present study, where the percentage of Tregs in peripheral blood of healthy dogs was $4.7 \%$, proving that Tregs do participate in physiologic processes.

When comparing Tregs expression in peripheral blood between dogs with lymphoma and healthy dogs (LG x CG), results showed that LG subjects expressed significantly higher numbers of Tregs compared to healthy dogs. Studies have demonstrated an increase on Tregs expression in peripheral blood, tumor tissues and lymph nodes during different malignant processes in humans, such as lung tumors, breast, ovarian and liver cancers, melanomas and lymphomas (Liyanage et al., 2002; Gray et al., 2003; Curiel et al., 2004; Alvaro et al., 2005; Ormandy et al., 2005; Baecher-allan et al., 2006). In addition, the clinical response to treatment in humans with cancer that exhibit an increase in Tregs expression is relatively unsuccessful (Baecherallan et al., 2006).

With the advance of research in this area, however, cancer patients with high expression of Regulatory $\mathrm{T}$ cells can now benefit from other therapeutic options such as the metronomic chemotherapy, in which drugs as cyclophosphamide given at low doses and for an extended period of time can decrease TCD $4{ }^{+} \mathrm{CD} 25^{+}$cells (Mutsaers, 2009).

In dogs, a number of research articles have been published based upon changes in $\mathrm{CD}^{+}$and Foxp $3^{+}$proportion of cells that occur in tumors (Gereda et al., 2000; Biller et al., 2007; O'neill et al., 2009; Horiuchi et al., 2009; Rissetto et al., 2010; Biller et al., 2010; Tominaga et al., 2010). A study comparing the percentage of Tregs between healthy dogs and those with diverse tumors such as round cell tumors, sarcomas and carcinomas, showed a higher Tregs expression both in peripheral blood and tumor tissue (Biller et al., 2007). However, some authors assert that carcinomas are associated with higher Tregs expression compared to other tumor types (O'neill et al., 2009).

There are few studies regarding Tregs expression in lymphomas, despite having a reduced number of cases, one study demonstrated high proportion of $\mathrm{CD}^{+}$and $\mathrm{Foxp}^{+}$cells in patients with lymphoma when compared to healthy dogs, similarly to the findings of the present study (O'neill et al., 2009).

In dogs with oral melanoma, despite the higher expression of Tregs compared to healthy dogs, a positive correlation with the clinical stage of the tumor was observed, showing that Tregs expression can be a prognostic marker in this disease (Tominaga et al., 2010). In canine osteosarcomas, the increase in Tregs was associated with a shorter overall survival of patients (Biller et al., 2010). Additionally, dogs with metastatic disease seemingly express more Tregs compared to dogs with malignant but nonmetastatic disease (Horiuchi et al., 2009).

In the present study, there was no significant difference in Tregs percentage between peripheral blood and lymph nodes of LG dogs. In a previous study using dogs with oral melanoma, the Tregs percentage was higher in tumor tissue compared to lymphnodes, suggesting that the site of tumor cell proliferation can be selectively infiltrated by these cells (Tominaga et al., 2010). Dogs with osteosarcoma showed no significant differences on Tregs expression between peripheral blood and lymph nodes, however, in tumoral sites, the percentage of Tregs was significantly higher compared to other first tissues (Biller et al., 2010). We believe that no 
significant difference of Tregs expression exists between peripheral blood and lymph nodes of dogs with lymphoma because this condition affects the hematopoietic system, which can contribute to similarities regarding Tregs expression in lymphoid tissue and peripheral blood.

\section{CONCLUSION}

We conclude that dogs with multicentric lymphoma have an increased percentage of Tregs on both peripheral blood and lymph nodes. This observation is of extreme importance since it can provide a better knowledge regarding the mechanisms involved in the pathogenesis of lymphoma and allows therapeutic regimens that suppress Tregs to be investigated as treatment options for dogs with lymphoma.

\section{ACKNOWLEDGEMENTS}

Financial Support: São Paulo Research Foundation (FAPESP).

\section{REFERENCES}

ALVARO, T.; LEJEUNE, M.; SALVADÓ, M.T. et al. Outcome in Hodgkin's lymphoma can be predicted from the presence of accompanying cytotoxic and regulatory $\mathrm{T}$ cells. Clin. Cancer Res., v.11, p.1467-1473, 2005.

BAECHER-ALLAN, C.; ANDERSON, D.E. Regulatory cells and human cancer. Semin. Cancer Biol., v.2, p.98-105, 2006.

BILLER, B.J.; ELMSLIE, R.E.; BURNETT, R.C. et al. Use of FoxP3 expression to identify regulatory $\mathrm{T}$ cells in healthy dogs and dogs with cancer. Vet. Immunol. Immunopathol., v.116, p.69-78, 2007.

COOLS, N.; PONSAERTS, P.; VAN TENDELOO, V.F.I. et al. Regulatory T cells and human disease. Clin. Dev. Immunol., v.2007, p.111, 2007.

CRUVINEL, W.M.; MESQUITA JR, D.; ARAÚJO, J.A.P. et al. Células $\mathrm{T}$ regulatórias naturais (Tregs) em doenças reumáticas. Rev. Bras. Reumatol., v.48, p.342-355, 2008.
CURIEL, T.J.; COUKOS, G.; ZOU, L. et al. Specific recruitment of regulatory $\mathrm{T}$ cells in ovarian carcinoma fosters immune privilege and predicts reduced survival. Nat. Med., v.10, p.942-949, 2004.

FEURER, M.; HILL, J.A.; MATHIS, D.; BENOIST, C. Foxp3+ regulatory $T$ cells: differentiation, specification, subphenotypes. Nat. Immunol., v.10, p.689-695, 2009.

GARDEN, O.A.; PINHEIRO, D.; CUNNINGHAM, F. All creatures great and small: regulatory $\mathrm{T}$ cells in mice, humans, dogs and other domestic animal species. Internat. Immunopharmacol., v.11, p.576-588, 2011.

GEREDA, J.E.; LEUNG, D.Y.M.; THATAYATIKON A. et al. Relation between house-dust endotoxin exposure, type 1 T-cell development, and allergen sensitisation in infants at high risk of asthma. Lancet, v.355, p.1680$1683,2000$.

GRAY, C.P.; AROSIO, P.; HERSEY, P. Association of increased levels of heavy-chain ferritin with increased CD4+ CD25+ regulatory T-cell levels in patients with melanoma. Clin. Cancer Res., v.9, p.2551-2559, 2003.

HORIUCHI, Y.; TOMINAGA, M.; ICHIKAWA, M. et al. Increase of regulatory T cells in the peripheral blood of dogs with metastatic tumors. Microbiol. Immunol., v.53, p.468-474, 2009.

ICHIHARA, F.; KONO, K.; TAKAHASHI, A. et al. Increased populations of regulatory $\mathrm{T}$ cells in peripheral blood and tumor-infiltrating lymphocytes in patients with gastric and esophageal cancers. Clin. Cancer Res., v.9, p.4404-4408, 2003.

ITOH, M.; TAKAHASHI, T.; SAKAGUCHI, N. et al. Thymus and autoimmunity: Production of CD251CD41 naturally anergic and suppressive T cells as a key function of the thymus in maintaining immunologic self-tolerance. $J$. Immunol., v.162, p.5317-5326, 1999.

LING, K.N.; PRATAP, S.E.; BATES, G.J. et al. Increased frequency of regulatory $\mathrm{T}$ cells in peripheral blood and tumour infiltrating lymphocytes in colorectal cancer patients. Cancer Immun., v.7, p.1-7, 2007. 
LIYANAGE, U.K.; MOORE, T.T.; JOO, H.G. et al. Prevalence of regulatory $\mathrm{T}$ cells is increased in peripheral blood and tumor microenvironment of patients with pancreas or breast adenocarcinoma. J. Immunol., v.169, p.27562761, 2002.

MUTSAERS, A.J. Metronomic chemotherapy. Top. Companion Anim. Med., v.24, p.137-143, 2009.

O'NEILL, K.; GUTH, A.; BILLER, B. et al. Changes in regulatory $\mathrm{T}$ cells in dogs with cancer and associations with tumor type. J. Vet. Int. Med., v.23, p.875-881, 2009.

ORMANDY, L.A.; HILLEMANN, T.; WEDEMEYER, H. et al. Increased populations of regulatory $\mathrm{T}$ cells in peripheral blood of patients with hepatocellular carcinoma. Cancer Res., v.65, p.2457-2464, 2005.
RISSETTO, K.C.; RINDT H.; SELTING K.A. et al. Cloning and expression of canine CD25 for validation of an anti-human CD25 antibody to compare $\mathrm{T}$ regulatory lymphocytes in healthy dogs and dogs with osteosarcoma. Vet. Immunol. Immunopathol., v.135, p.137-145, 2010.

SAKAGUCHI, S.; YAMAGUCHI, T.; NOMURA, T.; ONO, M. Regulatory T cells and immune tolerance. Cell. v.133, p.775-787, 2008.

SEQUEIRA, J.L.; FRANCO, M.; BANDARRA, E.P. et al. Características anatoclínicas dos linfomas caninos na região de Botucatu, São Paulo. Arq. Bras. Med. Vet. Zootec., v.51, p.1-11, 1999.

TOMINAGA, M.; HORIUCHI, Y.; ICHIKAWA, M. et al. Flow cytometric analysis of peripheral blood and tumor-infiltrating regulatory $\mathrm{T}$ cells in dogs with oral malignant melanoma. J. Vet. Diag. Investig., v.22, p.438$441,2010$. 